\title{
Autumn temperature and carbon balance of a boreal Scots pine forest in Southern Finland
}

\author{
T. Vesala ${ }^{1}$, S. Launiainen ${ }^{1}$, P. Kolari ${ }^{2}$, J. Pumpanen ${ }^{2}$, S. Sevanto ${ }^{3}$, P. Hari ${ }^{2}$, E. Nikinmaa ${ }^{2}$, P. Kaski ${ }^{4}$, H. Mannila ${ }^{5}$, \\ E. Ukkonen ${ }^{4}$, S. L. Piao ${ }^{6,7}$, and P. Ciais ${ }^{6}$ \\ ${ }^{1}$ Department of Physics, P.O. Box 48, 00014 University of Helsinki, Finland \\ ${ }^{2}$ Department of Forest Ecology, P.O. Box 27, 00014 University of Helsinki, Finland \\ ${ }^{3}$ Los Alamos National Laboratories P.O. Box 1663 MS J495 Los Alamos NM 87545-0001, USA \\ ${ }^{4}$ Department of Computer Science and Helsinki Institute for Information Technology HIIT, P.O. Box 68, \\ 00014 University of Helsinki, Finland \\ ${ }^{5}$ Helsinki Institute for Information Technology HIIT, P.O. Box 68, 00014 University of Helsinki, Finland \\ ${ }^{6}$ LSCE, UMR CEA-CNRS, Bat. 709, CE, L'Orme des Merisiers, 91191 Gif-sur-Yvette, France \\ ${ }^{7}$ Department of Ecology, Peking University, Beijing 100871, China
}

Received: 29 May 2009 - Published in Biogeosciences Discuss.: 16 July 2009

Revised: 4 December 2009 - Accepted: 11 December 2009 - Published: 13 January 2010

\begin{abstract}
We analyzed the dynamics of carbon balance components: gross primary production (GPP) and total ecosystem respiration (TER), of a boreal Scots pine forest in Southern Finland. The main focus is on investigations of environmental drivers of GPP and TER and how they affect the inter-annual variation in the carbon balance in autumn (September-December). We used standard climate data and $\mathrm{CO}_{2}$ exchange measurements collected by the eddy covariance (EC) technique over 11 years. EC data revealed that increasing autumn temperature significantly enhances TER: the temperature sensitivity was $9.5 \mathrm{gC} \mathrm{m}^{-2}{ }^{\circ} \mathrm{C}^{-1}$ for the period September-October (early autumn when high radiation levels still occur) and $3.8 \mathrm{gC} \mathrm{m}^{-2}{ }^{\circ} \mathrm{C}^{-1}$ for NovemberDecember (late autumn with suppressed radiation level). The cumulative GPP was practically independent of the temperature in early autumn. In late autumn, air temperature could explain part of the variation in GPP but the temperature sensitivity was very weak, less than $1 \mathrm{gC} \mathrm{m}^{-2}{ }^{\circ} \mathrm{C}^{-1}$. Two models, a stand photosynthesis model (COCA) and a global vegetation model (ORCHIDEE), were used for estimating stand GPP and its sensitivity to the temperature. The ORCHIDEE model was tested against the observations of GPP derived from EC data. The stand photosynthesis model COCA predicted that under a predescribed $3-6{ }^{\circ} \mathrm{C}$ temperature increase, the temperature sensitivity of $4-5 \mathrm{gC} \mathrm{m}^{-2}{ }^{\circ} \mathrm{C}^{-1}$ in GPP may appear in early autumn. The analysis by the ORCHIDEE model revealed the model sensitivity to the temporal treat-
\end{abstract}

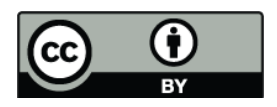

Correspondence to: $\mathrm{T}$. Vesala (timo.vesala@helsinki.fi) ment of meteorological forcing. The model predictions were similar to observed ones when the site level 1/2-hourly time step was applied, but the results calculated by using daily meteorological forcing, interpolated to 1/2-hourly time step, were biased. This is due to the nonlinear relationship between the processes and the environmental factors.

\section{Introduction}

The carbon balance of boreal forest ecosystems is sensitive to prevailing weather conditions. In the summertime these ecosystems are clear sinks of carbon, but in the winter they become small carbon sources because carbon uptake via photosynthesis decreases more than respiration (e.g. Suni et al., 2003; Lagergren et al., 2008). The timing of the sinkto-source and source-to-sink turning points in the autumn and spring depends on temperature (e.g. Pelkonen and Hari, 1980; Suni et al., 2003). Therefore, the annual balance is affected especially by the temperature in the autumns and springs (Mäkelä et al., 2006). During those periods, the difference in temperature sensitivity of photosynthesis and respiration processes is an important controller of the carbon balance.

According to future climate projections, boreal and arctic regions will be exposed to stronger warming than any other region of the world. The first signs of the high latitude warming are already observable (IPCC, 2007). According to the climate simulations, the mean annual air temperatures in northern Europe are expected to increase between $2-6^{\circ} \mathrm{C}$ during this century and the increase is likely to be strongest

Published by Copernicus Publications on behalf of the European Geosciences Union. 
during winter months (Christensen et al., 2007), lengthening the autumn period and making the spring start earlier. Over the past decade the autumn temperature has increased by almost $1{ }^{\circ} \mathrm{C}$ over the northern latitudes.

Recently, Piao et al. (2008) published results which showed that $\mathrm{CO}_{2}$ records from the past 20 years exhibit a trend towards earlier autumnal carbon dioxide build-up in the atmosphere, a signal interpreted as resulting from increasing carbon losses from boreal forests ecosystems during warmer autumns. Overall, the earlier autumn build-up dominates over the earlier spring draw-down of $\mathrm{CO}_{2}$, which means that the length of the net Carbon Uptake Period (CUP) has been shrinking over the past 2 decades. The CUP is defined as the duration of the period of the year during which the ecosystem is a net sink of atmospheric $\mathrm{CO}_{2}$. According to Piao et al. (2008) the large scale inferences based on atmospheric $\mathrm{CO}_{2}$ concentration records were partly corroborated by eddy covariance (EC) flux tower data from 24 northern ecosystem sites. The flux tower data from North American, Siberian, and northern European boreal forests, all lumped together, suggested as well that the CUP terminates systematically earlier when autumn conditions get warmer. The strong positive temperature anomalies were associated with strong release of $\mathrm{CO}_{2}$ to the atmosphere in autumn. However, the strongest negative temperature anomalies, autumns with temperature more than $2{ }^{\circ} \mathrm{C}$ below the average, did not provoke much larger $\mathrm{CO}_{2}$ sink than normal, suggesting a complex response of ecosystems to autumn temperature.

EC data represents net carbon exchange at ecosystem scale (net ecosystem exchange, NEE), which is negative when the ecosystem acts as a net sink. NEE is the sum of gross primary production (GPP), which represents the net photosynthesis, and total ecosystem respiration (TER). Thus NEE = - GPP + TER, where GPP and TER are always positive by definition. TER is furthermore the sum of two respiration processes, autotrophic and heterotrophic ones, and nighttime TER can be measured by EC method, whereas daytime TER or GPP cannot be directly detected by EC method. GPP depends strongly on irradiance (PAR), physiological state of the ecosystem, and water and nutrient availability (e.g. Larcher, 1975; Running and Gower, 1991). TER consists of respiration of the aboveground biomass and the roots and the rhitzosphere as well as decomposition in the soil. The respiratory processes are often considered primarily as temperaturedriven although they ultimately rely on substrate availability and are coupled with photosynthesis (e.g. Högberg et al., 2001).

Since the EC measurements of NEE cannot discriminate GPP and TER, the gross fluxes are usually estimated indirectly by determining the temperature response of TER using night-time measurements and extrapolating to daytime or by model-assisted procedures (Reichstein et al., 2005). In the study by Piao et al. (2008), the ORCHIDEE terrestrial ecosystem model was to quantify the impacts of autumn warming on GPP and TER. The model results suggested that the reason for elevated carbon losses in warm autumns is the stronger positive temperature sensitivity of TER compared to GPP. In the autumn, the day length has been used as a proxy for GPP limitation (Suni et al., 2003; Mäkelä et al., 2006; Bergeron et al., 2007). Thus, any changes in temperature are likely to be more strongly reflected in respiration rate rather than in assimilation. The model analysis performed by Piao et al. (2008) was focused on a biome-scale response of boreal and temperate forests but did not look into any specific features of an individual ecosystem. Acquiring greater understanding of responses of an individual ecosystem to autumn climate is important for defining more realistic scenarios of ecosystem-specific climate-change induced alterations and for future developments of generic simulation models.

The boreal coniferous forests are widely distributed covering approximately 10 million $\mathrm{km}^{2}, 7 \%$ of the earth land surface (FAO 2000). Boreal forest soils are among the largest terrestrial carbon pools, estimated to contain approximately $15 \%$ of the soil C storage world wide (Schlesinger, 1977; Post et al., 1982). In this study we will test the hypothesis that the autumn temperature has a significant effect to concomitant TER and that subsequent variations in TER are important to overall carbon balance of a boreal forest stand. The main goal is in investigations of the environmental drivers of NEE (GPP and TER) focusing on the autumn period. We analyze the effect of autumn climate, temperature in particular, to the carbon balance of a boreal Scots pine forest, which is one of the main species in boreal region. We quantify the sensitivity of TER, GPP and NEE to their environmental drivers utilizing eleven years of EC data collected at SMEAR II - station located in Hyytiälä, Southern Finland (Hari et al., 2008a). In addition we use two models, the stand photosynthesis model COCA (Vesala et al., 2000, Kolari et al., 2006) and the dynamic global vegetation model ORCHIDEE (Krinner et al., 2005), for estimating stand GPP and its sensitivity to the temperature. The ORCHIDEE model is tested against the obtained results and a sensitivity analysis on the temporal treatment of meteorological forcing is performed.

\section{Materials and methods}

\subsection{Site description}

The SMEAR II station is located in a relatively homogenous Scots pine stand (Pinus sylvestris L.) sown in 1962 next to the Hyytiälä forest station of the University of Helsinki in southern Finland $\left(61^{\circ} 51^{\prime} \mathrm{N}, 24^{\circ} 17^{\prime} \mathrm{E}, 181 \mathrm{~m}\right.$ a.s.l.). From 1970 to 2000 , the site mean annual temperature was $+3.3^{\circ} \mathrm{C}$ and precipitation $713 \mathrm{~mm}$. The mean depth of the soil organic layer is $5.4 \mathrm{~cm}$ and density $0.13 \mathrm{~g} \mathrm{~cm}^{-3}$. The forest floor vegetation is dominated by dwarf shrubs and mosses (Kulmala et al., 2008). According to the Cajander site classification system based on ground vegetation species composition (Cajander, 1909), the stand is of medium quality and has 
a current growth rate of $8 \mathrm{~m}^{3} \mathrm{ha}^{-1} \mathrm{yr}^{-1}$. The forest is in the middle of its commercial rotation time for this type of stand. It has been regenerated according to standard silvi-cultural guidelines (Peltola, 2001) and is therefore representative for a typical managed pine forest. The mean tree height has increased from about 13 to $16 \mathrm{~m}$ during the eleven-year period studied since 1996. The total all-sided leaf area index (LAI) was approximately $7 \mathrm{~m}^{2} \mathrm{~m}^{-2}$; there was a slight increasing trend in LAI during the studied years and a momentary decrease in winter 2002 when some parts of the stand were thinned (Vesala et al., 2005). The earlier level in LAI was, however, re-established in few years (Ilvesniemi et al., 2009). The thinning had no detectable effect on NEE, GPP and TER compared to the natural inter-annual variability; increased photosynthesis of ground vegetation more or less compensated for the small decline in canopy GPP and the reduction in root respiration was of similar magnitude as the additional $\mathrm{CO}_{2}$ efflux from decaying harvesting residue (Vesala et al., 2005; Lagergren et al., 2008; Ilvesniemi et al., 2009).

\subsection{Data processing and modelling}

\subsubsection{Eddy covariance data and its partitioning and gap filling}

The basic dataset used in this study consists of eleven years of 1/2-hourly $\mathrm{CO}_{2}$ flux measurements of the net ecosystem exchange (NEE) complemented by climate and ecosystem data. In this study we utilize the eddy covariance (EC) data measured continuously from 1997 to 2007. The flux measurements were made at $23.3 \mathrm{~m}$ height (at $46.6 \mathrm{~m}$ - from October 1998 through June 2000). The measurements, data processing and flux calculations are performed according to standard procedures (Aubinet et al., 2000) and the details of the measurement setup are described, for instance, in Markkanen et al. (2001). The half-hourly averaged fluxes were filtered for low turbulence conditions ( $\mathrm{u} *-$ threshold) as described in Markkanen et al. (2001) and corrected for changes in storage of $\mathrm{CO}_{2}$ below the measuring height. We define the autumn as 1 September to 31 December. The autumn is further divided into two periods: Early autumn (September-October) and late autumn (NovemberDecember), which are considered separately. This selection is made because GPP has minor effect on late autumn NEE and the role of the environmental drivers is drastically different between early and late autumn periods.

Partitioning of NEE into TER $\left(R_{\mathrm{e}}\right)$ and GPP $(P)$ was done in the following way (see details in Kolari et al., 2009). $R_{\mathrm{e}}$ was modelled using a modified Arrhenius type exponential equation (Lloyd and Taylor, 1994):

$R_{\mathrm{e}}=R_{\mathrm{e}, 0} \mathrm{e}^{E\left(1-\frac{T_{0}}{T_{\mathrm{S}}}\right)}$

where $T_{S}$ is temperature $\left({ }^{\circ} \mathrm{C}\right)$ at a depth of $2 \mathrm{~cm}$ in the soil organic layer, $R_{\mathrm{e}, 0}$ the average night-time turbulent flux at soil temperature $T_{0}$, and $E$ a temperature sensitivity parameter.
Half-hourly fluxes fulfilling the turbulence criteria were used for deriving GPP $(P)$ directly from the measured NEE $(F)$ as

$P=-F+R_{\mathrm{e}}$

During periods of weak turbulence, GPP was gap-filled with a simple empirical model, as a saturating function of light with a nonrectangular hyperbola

$$
P=\frac{1}{2 \theta_{\text {con }}}\left[\alpha I+P_{\max }-\sqrt{\left(\alpha I+P_{\max }\right)^{2}-4 \theta_{\operatorname{con}} \alpha I P_{\max }}\right],
$$

where $I$ is the incident photosynthetically active radiation (PAR, $\mu$ mol m $\left.{ }^{-2} \mathrm{~s}^{-1}\right), P_{\max }\left(\mu \mathrm{mol} \mathrm{m}{ }^{-2} \mathrm{~s}^{-1}\right)$ the rate of saturated photosynthesis, $\theta_{\text {con }}$ (dimensionless) a parameter defining the convexity of the light response curve, and $\alpha$ (dimensionless) the initial slope of the curve. The gap-filling model parameters were derived from GPP estimates from measured fluxes and measured light values.

The temperature sensitivity of ecosystem respiration was derived from regressions of accepted night-time turbulent fluxes and temperature in the soil organic layer over the growing season. To take into account the inter-annual and seasonal variations in the photosynthetic light response and respiration, the base level of respiration $R_{\mathrm{e}, 0}$ and the parameters $\alpha$ and $P_{\text {max }}$ in the photosynthesis model were estimated for each day of the year using a 9-day moving window of accepted flux data. The parameters were estimated simultaneously using both night-time and daytime measurements within the same time window (more detailed description in Kolari et al., 2009).

\subsubsection{Stand photosynthesis model}

We estimated stand GPP using a model COCA (COmplex CAnopy Model) for photosynthesis of the tree canopy and the forest floor vegetation (Vesala et al., 2000, Kolari et al., 2006). The photosynthesis component of the model combines the optimal stomatal control model (Hari et al., 1986) with an annual cycle model (Mäkelä et al., 2004). The key parameter that varies seasonally in the optimal stomatal control model is photosynthetic efficiency $\beta$ that varies seasonally. Mäkelä et al. (2004) found that the annual variation in photosynthetic efficiency in boreal Scots pine can be accurately explained by ambient temperature history $S$ by

$$
\frac{d S}{d t}=\frac{T-S}{\tau}
$$

where $T\left({ }^{\circ} \mathrm{C}\right)$ is the ambient air temperature and $\tau$ a time constant $(200 \mathrm{~h})$. In the model simulations, $S$ for each moment of time $i$ was calculated with a time step $\Delta t$ of $30 \mathrm{~min}$

$S_{i}=S_{i-1}+\frac{T_{i}-S_{i-1}}{\tau} \Delta t$ 
The initial value of $S$ was set equal to the first temperature record of the climatic data. The relationship between $\mathrm{S}$ and daily photosynthetic efficiency $\beta$ was modeled as a sigmoidal response to temperature history (Kolari et al., 2007).

$\beta=\frac{\beta_{\max }}{1+e^{b\left(S-T_{S}\right)}}$

where $\beta_{\max }$ is the seasonal maximum of photosynthetic efficiency. $T_{s}\left({ }^{\circ} \mathrm{C}\right)$ is the inflection point, i.e. the value of $S$ at which $\beta$ reaches half of $\beta_{\max }$, and $b$ curvature of the function. The slow temperature response was further modified by introducing the instantaneous response of $\beta$ to freezing temperatures and the carry-over effect from nighttime frost (Kolari et al., 2007), as a multiplier that varied between 0 and 1 . The value of the frost modifier was 1 if the minimum air temperature in the previous night was above zero. Below $0{ }^{\circ} \mathrm{C}$ the modifier decreased linearly with temperature, reaching zero at $-10^{\circ} \mathrm{C}$. The values of the photosynthetic model parameters and the annual cycle parameters were based on gas exchange measurements with chambers on several pine shoots in Hyytiälä in 2000-2005 (Kolari et al., 2007).

The stand photosynthesis model COCA was applied in half-hour time steps over the autumns (SeptemberDecember) of 1997-2007. The model input included meteorological data measured at the site with all half-hourly temperature records raised by the increase in annual mean temperature for different climate warming scenarios (present, $3^{\circ} \mathrm{C}$ and $6^{\circ} \mathrm{C}$ ). The relative humidity remained unaltered and the present-day atmospheric $\mathrm{CO}_{2}$ data was used to extract the effect of temperature on photosynthesis.

\subsubsection{Global vegetation model}

The ORCHIDEE model (Krinner et al., 2005) represents key vegetation processes governing terrestrial biogeochemistry and biogeography. ORCHIDEE consists of five vegetation carbon reservoirs, four litter reservoirs, and three soil reservoirs. Plant $\mathrm{CO}_{2}$ assimilation in ORCHIDEE model is based on work by Farquhar et al. (1980) for C3 plants and Collatz et al. (1992) for C4 plants. Maintenance respiration is a function of each living biomass pool and temperature, while growth respiration is computed as a fraction of the difference between assimilation inputs and maintenance respiration outputs to plant biomass. Heterotrophic respiration parameterization is taken from CENTURY (Parton et al., 1988), which includes three soil carbon pools: active, slow and passive carbon. Decomposition rate of each pool is a function of soil moisture and temperature. Many terrestrial biosphere models operate, for computational efficiency, on daily or on monthly time steps. However, the time step affects the results due to non-linear responses of processes to the meteorological forcing. To test the temporal sensitivity we performed two ORCHIDEE simulations at different time steps: half-hourly and daily time step. In each simulation, we first run the model until ecosystem carbon pools reach steady-state equilibrium (long-term mean annual NEE $\approx 0$ ), using the observed corresponding meteorology data (half-hourly or daily) for 1997. Starting from this equilibrium state, the model is integrated for eleven years (1997-2007) forced by the climate data measured at the study site.

\section{Results and discussion}

This section is structured as follows: First we discuss the general climate conditions and seasonal climate constraints at the site and show how the importance of different environmental variables behind the carbon dynamics varies throughout the year. Secondly we consider the autumn carbon balance and its variability using ecosystem scale EC measurements and discuss the expected changes in GPP in elevated temperatures using the COCA model. Finally, the predictions of the ORCHIDEE model are considered paying special attention to the sensitivity on the forcing time step.

\subsection{Seasonality and environmental controllers}

The climate in the boreal zone is characterized by strong seasonal variation with cold, dark winters and rather warm irradiation-rich summers. Accordingly, the annual cycle in photosynthesis is strong in the boreal forest. There is intensive sugar formation in summer and very small, if any, photosynthesis activity in winter, since there is little sunlight available. The low irradiation levels start to inhibit the photosynthesis already in October-November, although the temperature would be well above $0{ }^{\circ} \mathrm{C}$. The warm soil still allows for rather high soil respiration levels. Radiation and temperature are environmental key factors which control the ecosystem net carbon balance in the autumn. To illustrate the autumn period in context of the annual cycle of environmental factors and of carbon exchange we first consider the whole-year dynamics of the variables and their correlations and thereafter the focus is on the autumn period.

Figure 1 shows the seasonality of the most important climate variables controlling the carbon fluxes. In Fig. 1 the correlation coefficient $(r)$ was calculated from daily averages in a 30-day moving window; e.g. the plotted value for 30 September is the linear correlation coefficient of daily averages in the window 1 September-30 September, concatenated over the years 1996-2007. Pooling all years (except 2006) before calculating the correlation coefficients combines short-term variability and inter-annual variability and the results in Fig. 1 thus represent a typical seasonal course rather than details of a specific year or period. For the same reason we omitted year 2006 here because a separate analysis revealed that the strong drought anomaly in the late summer (August) of 2006 affected significantly the results.

GPP correlated best with air temperature in the spring, but in the autumn the stand photosynthesis was mostly determined by radiation (Fig. 1). The correlation between GPP 


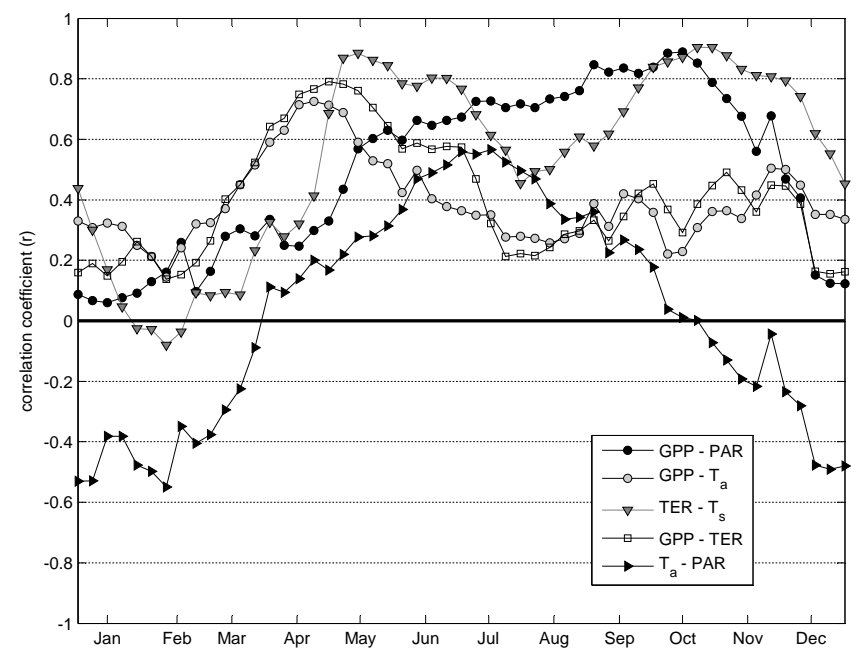

Fig. 1. Temporal variation of the correlation coefficient $(r)$ between GPP and TER and their expected drivers: air temperature $\left(T_{a}\right)$ soil temperature $\left(T_{S}\right)$, (B-horizon, 10-25 cm depth) and photosynthetically active radiation (PAR). $r$ is calculated from daily mean values within a 30-day moving window (29 day overlap) using data from years 1997-2005 and 2007. Values of $r$ are shown at 7 day intervals.

and $T_{a}$ was order of +0.5 to +0.7 in the spring (MarchMay). As the growing season progressed, the correlation between GPP and $T_{a}$ decreased and the correlation with PAR increased peaking in September-October $(>+0.8)$. Thus, the primary controlling factors in springtime and later in the summer were different. During the rest of the year (winter and late autumn) both correlations remained small, less than +0.4 , but GPP itself was also very small (see Fig. $3 \mathrm{c}$ ). The correlation between TER and the soil temperature was strongest $(r \sim+0.9)$ in May and early autumn (SeptemberNovember) but dropped slightly in July-August because that period is often dry and soil moisture limitations has decreases TER. In December the correlation between TER and $T_{s}$ decreased rapidly and remained below +0.3 through the winter, while the respiration level was low and the soil temperature stable. Note that the environmental factors are also correlated. Most importantly, the relationship between daily radiation and temperature depends on the season and Fig. 1 reveals the typical features of the high-latitude weather patterns. In summer the clear skies (high radiation) lead to larger than average daily temperatures $(r \sim+0.5)$ while during the winter and autumn the clear days are typically cold $(r \sim-0.5)$ and the warm spells are associated with westerlies from the North Atlantic, which typically create cloudy and moist conditions at the region.

There were three distinguishable years in terms of climate extremes in the autumn (Fig. 2). Autumn 2002 was exceptionally dry and cool whereas autumns 2000 (not shown separately) and 2006 were warm and moist. The autumn 2006 was significantly warmer than average especially in December whereas 2002 was colder, drier and clearer than aver-
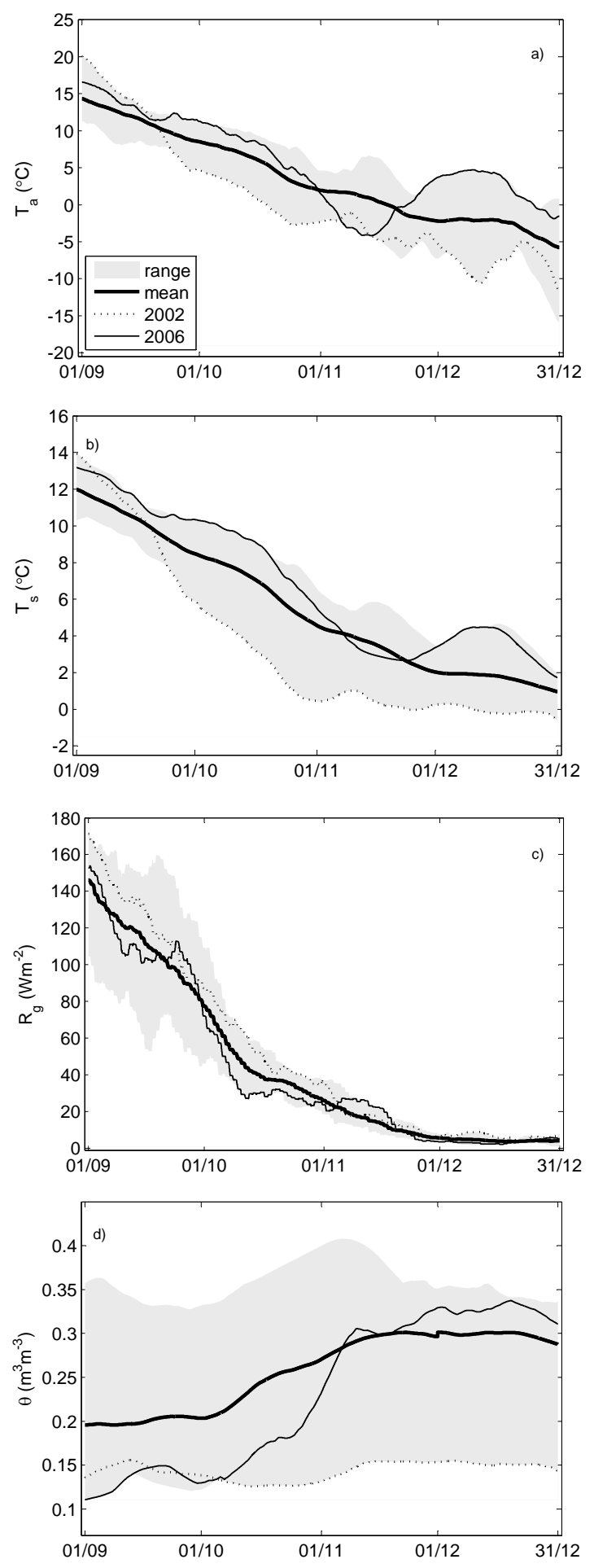

Fig. 2. The climate conditions. (a) air temperature $\left(T_{a}\right)$, (b) soil temperature $\left(T_{S}\right)$, (c) global radiation $\left(R_{\mathrm{g}}\right)$ and $(\mathbf{d})$ volumetric soil water content $(\theta)$. The average and the extreme years (2002 and 2006) are shown separately and the shaded area shows the variability range during 1997-2007. All values are 14-day running averages. 
age in October-December. The large positive temperature anomaly in December 2006 is apparent also in soil temperature $\left(T_{s}\right)$ (Fig. 2b). In general, air temperature $\left(T_{a}\right)$ decreased gradually during the autumn from $\sim 12-20^{\circ} \mathrm{C}$ in early September to -15 to $+1^{\circ} \mathrm{C}$ in late December. Similarly to $T_{a}, T_{s}$ decreased from values around $11-14{ }^{\circ} \mathrm{C}$ to 0 to $+2{ }^{\circ} \mathrm{C}$ during the course of the autumn. Soil temperature seldom reached the freezing point because of the insulating effect of snow and large heat capacity of the moist soil. Only in 2002 soil frost occurred because of low soil moisture content $(\theta)$ (see Sevanto et al., 2006). The global radiation $\left(R_{\mathrm{g}}\right)$ decreased rapidly from September to November because of the northern location of the site (Fig. 2c). The inter-annual variability of $R_{\mathrm{g}}$ is relatively large in early autumn with the extremes occurring in 2001 and 2003 (cloudy) and 1999 and 2000 (clear) (the values not shown). The $\theta$ varies strongly both within and between the autumns (Fig. 2d). Typically $\theta$ is lowest $\left(\sim 0.2 \mathrm{~m}^{3} \mathrm{~m}^{-3}\right)$ at the end of the summer and a gradual recharge of the water content occurs in late SeptemberNovember depending on the amount of precipitation. The extreme autumns in terms of soil moisture content were 1998 (moist) and 2002 (dry and cold). In summer 2006 the forest was suffering from intensive drought (not shown), which reduced both the ecosystem respiration and gross photosynthesis and turned the stand to be a carbon source (Duursma et al., 2007) over two weeks in August. As a consequence, the early autumn (September-October) 2006 has the lowest $\theta$ values but in November the soil moisture content returned to the typical level.

\subsection{Temporal variability of GPP and TER}

Similarly to the climatic variables we show the general behavior and the extreme values of carbon cycle components during 1 September-31 December in 1997-2007. The mean 14-day NEE (Fig. 3a) varied from -0.3 to $-2.2 \mu \mathrm{mol} \mathrm{m}^{-2} \mathrm{~s}^{-1}$ (average $-1.2 \mu \mathrm{mol} \mathrm{m}^{-2} \mathrm{~s}^{-1}$ ) in early September and remained negative in most of the autumns until early October when the ecosystem turned into a cumulative source for atmospheric $\mathrm{CO}_{2}$ (Fig. 3b). In late autumn (November-December) the temporal variability of NEE was small. However, the exceptionally warm December 2006 differed from the other autumns by high respiration values, whereas the cold December 2002 was accompanied by somewhat lower NEE values than the average. The CUP end was defined as the last day when 5-day average NEE was negative (Piao et al., 2008). On average, it occured on day 284 (11 October). The earliest CUP end was on day 272 (29 September) in 1999 and 2006 and the latest on day 295 (22 October) in 2005. However, there was no correlation between CUP end and mean autumn temperature, which was defined in 60day window around the mean CUP ending.

The mean 14-day GPP varied from 6.5 to $4.7 \mu \mathrm{mol} \mathrm{m}^{-2} \mathrm{~s}^{-1}$ in early September to less than $0.2 \mu \mathrm{mol} \mathrm{m}^{-2} \mathrm{~s}^{-1}$ in December (Fig. 3c). The inter- annual variability of GPP in early autumn was strongly linked to changes in radiation (Fig. 2c). The autumns with lowest $R_{\mathrm{g}}$ had generally the lowest GPP (2004, 2003 and 2001) (not shown). In particular, the strong decrease in photosynthesis in mid-September 2001 (lowest September value in Fig. 3c) was caused by an extremely cloudy period when $R_{\mathrm{g}}$ was around half of the typical level. The major fraction of the autumnal carbon assimilation happened in early autumn (September-October). Also the inter-annual variability was much larger in absolute sense in SeptemberOctober period than in November-December. Late autumn (November-December) contributed only between 1\% (2002) to $7 \%$ (2004) to the total autumn GPP (Fig. 3d). Therefore, the climate changes taking place in late autumn seems likely to have negligible effect on annual GPP, which is confirmed by the model analysis later.

TER is correlated with the soil (and to some extent air) temperature and its highest 14-day average values (3.7$5.1 \mu \mathrm{mol} \mathrm{m}{ }^{-2} \mathrm{~s}^{-1}$ ) occurred in early September (Fig. 3e). The inter-annual variability of TER, both in absolute (in $\mu \mathrm{mol} \mathrm{m}{ }^{-2} \mathrm{~s}^{-1}$ ) and relative sense was markedly larger than in GPP, especially in late autumn. The carbon emissions during cool and dry 2002 were consistently smaller than in other autumns (Fig. 3f). In proportion, the moist and warm autumns 2000 (not shown) and 2006 had the highest cumulative respiration. Contrary to GPP, the late autumn contributed significantly to the autumnal ecosystem respiration - the contribution varied from $20 \%$ (2002) to $29 \%$ (2003).

The autumn contributes significantly to annual TER but less so to annual GPP: The annual TER was on average $823 \mathrm{gC} \mathrm{m}^{-2}$ (range $763-858 \mathrm{gC} \mathrm{m}^{-2}$ ) and of this the autumn contributes on average $26 \%$. The largest contribution (32\%) occurs in 2006 and minimum (19.5\%) in 2002, which was the coldest and driest autumn. Thus, autumn TER is crucial both because it is roughly $1 / 4$ of annual but also because the variability of autumn TER $\left(95 \mathrm{gC} \mathrm{m}^{-2}\right)$ is comparable to the inter-annual variability $\left(136 \mathrm{gC} \mathrm{m}^{-2}\right)$. In contrary to TER the autumn GPP is only $4.0 \%$ (range $3.6-4.3 \%$ ) of the annual that is on average $1032 \mathrm{gC} \mathrm{m}^{-2}$ (range $952-1104 \mathrm{gC} \mathrm{m}^{-2}$ ). The annual GPP is much more sensitive to the onset ofthe growing season which depends on the spring temperature conditions (Suni et al., 2003).

Overall, the connection between climate and NEE is not straightforward and its implications change from one season to another. Warming in late autumn/winter will lead to increased respiration, but in spring to enhanced photosynthesis. In summer, the warming can trigger drought effects. Predicting the inter-annual variations and dynamics of the carbon exchange under the changing climate requires detailed information on the intra-annual connections between climate factors and seasonal carbon cycling (see Fig. 1) and the usage of simple proxies, such as the change of the annual temperature, for predictions can lead to a biased view. 

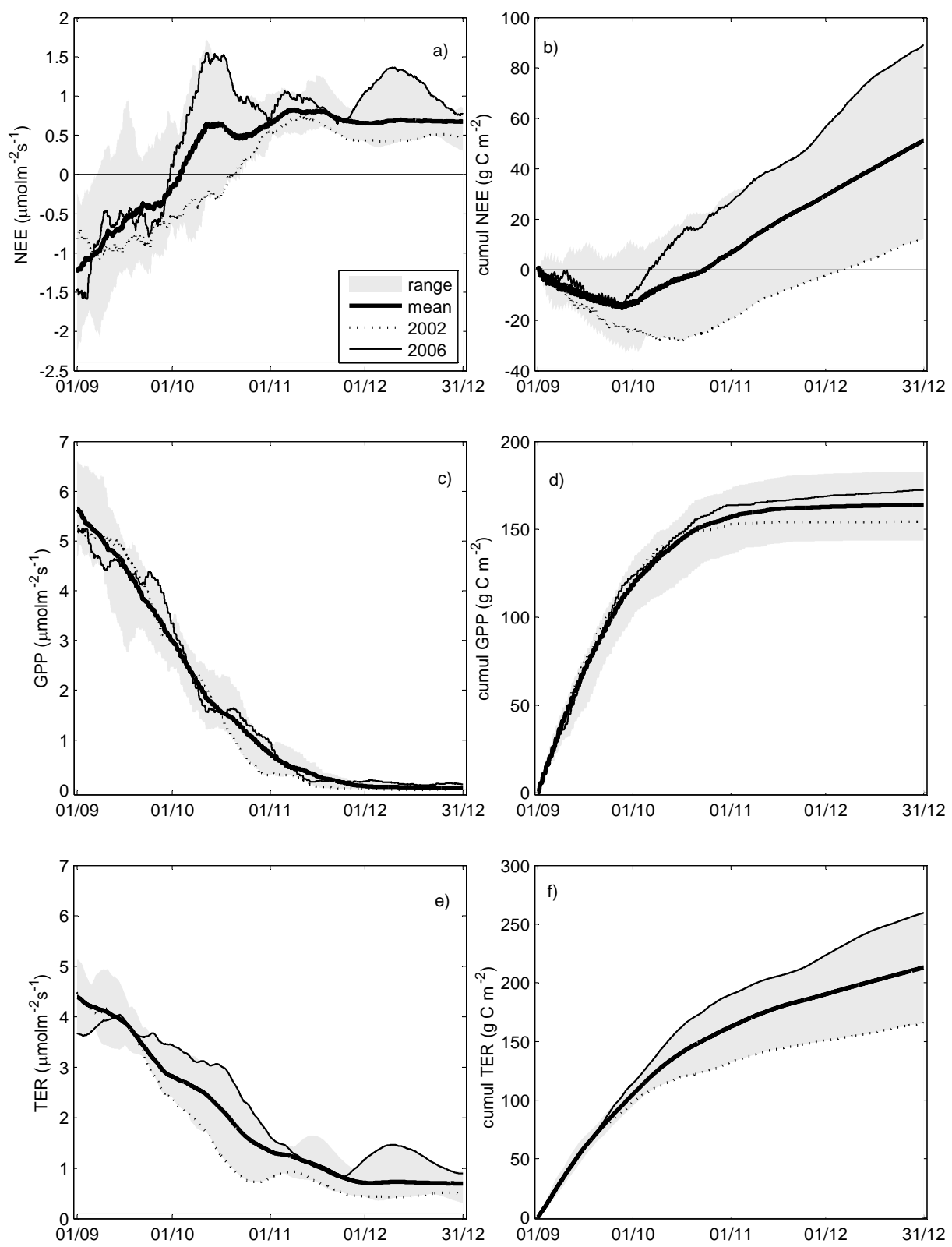

Fig. 3. Net ecosystem exchange (NEE), gross primary productivity (GPP) and ecosystem respiration (TER) as 14-day running mean (left) and their cumulative values (right). The symbols are as in Fig. 1.

\subsection{Bivariate and partial correlations}

Table 1 shows the average bivariate correlation coefficients between cumulative carbon balance components and mean climate parameters in early (September-October) and late autumn (November-December) periods, respectively. Since the climate variables are correlated with each other, we calculated also the partial correlations (Table 2) between the carbon fluxes (i.e. GPP and TER) and either $T_{a}$, PAR or $\theta$ by controlling the effect of the two other independent variables. $T_{s}$ was removed from the analysis because of collinearity with $T_{a}$.
The correlation analysis confirms the importance of temperature in autumn carbon balance. In early autumn the partial correlation between $T_{a}$ and NEE $(+0.70)$ and TER $(+0.81)$ are highly significant $(\mathrm{p}<0.01)$ and the same holds also for late autumn. In early autumn NEE correlates significantly with PAR (partial correlation coefficient $r=-0.78$, $\mathrm{p}<0.05$ ) but the relationship weakens and becomes nonsignificant in late autumn $(r=0.35, \mathrm{p}>0.05)$. Partial correlation coefficient between GPP and $\mathrm{T}_{\mathrm{a}}$ increases from early $(+0.44)$ to late autumn $(+0.56)$ while GPP-PAR relationship weakens $(-0.60$ and 0.33 , respectively). These correlations are however statistically non-significant. Also the bivariate $r$ 
Table 1. Bivariate correlation coefficients $(\mathrm{N}=11)$ between cumulative carbon balance (NEE), its components (GPP, TER) and mean climate variables air $\left(T_{a}\right)$ and soil temperature $\left(T_{S}\right)$, photosynthetically active radiation (PAR) and volumetric soil moisture content $(\theta)$ in early (September-October) and late autumn (November-December). Statistically significant correlations are marked with $* *(2$-tailed $\mathrm{p}<0.01)$ and $*(\mathrm{p}<0.05)$

(a) Early autumn

\begin{tabular}{lrrrrrrr}
\hline & NEE & GPP & TER & $T_{a}$ & $T_{s}$ & PAR & $\theta$ \\
\hline NEE & 1 & -0.40 & $0.79(* *)$ & $0.69(*)$ & $0.77(* *)$ & $-0.79(* *)$ & 0.35 \\
GPP & -0.40 & 1 & 0.25 & 0.14 & 0.09 & 0.53 & -0.23 \\
TER & $0.79(* *)$ & 0.25 & 1 & $0.83(* *)$ & $0.88(* *)$ & -0.46 & 0.18 \\
$T_{a}$ & $0.69(*)$ & 0.14 & $0.83(* *)$ & 1 & $0.94(* *)$ & -0.39 & 0.27 \\
$T_{S}$ & $0.77(* *)$ & 0.09 & $0.88(* *)$ & $0.94(* *)$ & 1 & -0.56 & 0.23 \\
PAR & $-0.79(* *)$ & 0.53 & -0.46 & -0.39 & -0.56 & 1 & -0.52 \\
$\theta$ & 0.35 & -0.24 & 0.18 & 0.27 & 0.23 & -0.52 & 1
\end{tabular}

(b) Late autumn

\begin{tabular}{lrrrrrrr}
\hline & NEE & GPP & TER & $T_{a}$ & $T_{s}$ & PAR & $\theta$ \\
\hline NEE & 1 & $0.67(*)$ & $0.99(* *)$ & $0.80(* *)$ & $0.78(* *)$ & -0.21 & 0.32 \\
GPP & $0.67(*)$ & 1 & $0.79(* *)$ & $0.66(*)$ & $0.71(*)$ & -0.10 & 0.57 \\
TER & $0.99(* *)$ & $0.79(* *)$ & 1 & $0.81(* *)$ & $0.81(* *)$ & -0.19 & 0.38 \\
$T_{a}$ & $0.80(* *)$ & $0.66(*)$ & $0.81(* *)$ & 1 & $0.86(* *)$ & -0.47 & 0.59 \\
$T_{s}$ & $0.78(* *)$ & $0.71(*)$ & $0.81(* *)$ & $0.86(* *)$ & 1 & -0.54 & 0.60 \\
PAR & -0.21 & -0.10 & -0.19 & -0.47 & -0.54 & 1 & -0.25 \\
$\theta$ & 0.32 & 0.57 & 0.38 & 0.59 & 0.60 & -0.25 & 1 \\
\hline
\end{tabular}

Table 2. Partial correlations $(\mathrm{N}=11)$ between cumulative carbon fluxes (NEE, GPP and TER) and air temperature $\left(T_{a}\right)$, photosynthetically active radiation (PAR) and volumetric soil moisture content $(\theta)$. The partial correlations with respective environmental variable were calculated by controlling for the effects of the two other variables. Statistically significant correlations are marked with $* *(2$-tailed $\mathrm{p}<0.01)$ and $*(\mathrm{p}<0.05)$.

(a) Early autumn

\begin{tabular}{lrrr}
\hline & $T_{a}$ & PAR & $\theta$ \\
\hline NEE & $0.70(*)$ & $-0.78(*)$ & -0.23 \\
GPP & 0.44 & 0.60 & 0.02 \\
TER & $0.81(* *)$ & -0.35 & -0.24 \\
\hline
\end{tabular}

(b) Late autumn

\begin{tabular}{lrrr}
\hline & $T_{a}$ & PAR & $\theta$ \\
\hline NEE & $0.82(* *)$ & 0.35 & -0.35 \\
GPP & 0.56 & 0.33 & 0.30 \\
TER & $0.82(* *)$ & 0.39 & -0.24 \\
\hline
\end{tabular}

between TER and soil and air temperature was high (around $+0.8, \mathrm{p}<0.01$ ) both in the early and late autumn. The bivariate $r$ between GPP and $T_{a}$ was low $(+0.14)$ in early autumn but became statistically significant in November-December $(+0.66, \mathrm{p}<0.05)$.

\subsection{Temperature sensitivity of measured GPP and TER}

A distinct relationship between average $T_{a}$ and the cumulative NEE existed for both early and late autumn periods (Fig. 4a). The correlation was higher for NovemberDecember when GPP was very small and NEE was practically the same as respiration, which depends on temperature. The temperature sensitivity of the early autumn $\mathrm{NEE}$ was more than $8 \mathrm{gC} \mathrm{m}^{-2}{ }^{\circ} \mathrm{C}^{-1}$ whereas it was close to $3 \mathrm{gC} \mathrm{m}^{-2}{ }^{\circ} \mathrm{C}^{-1}$ in the late autumn. The cumulative GPP was practically independent of the temperature in the early autumn $\left(R^{2}=0.02\right)$ (Fig. 4b). In the late autumn the air temperature could explain $43 \%$ of the variation in GPP $\left(R^{2}=0.43\right)$ but the temperature sensitivity was very weak, less than $1 \mathrm{gC} \mathrm{m}^{-2}{ }^{\circ} \mathrm{C}^{-1}$. The highest $R^{2}$ values existed for TER and its temperature sensitivity was almost $10 \mathrm{gC} \mathrm{m}^{-2}{ }^{\circ} \mathrm{C}^{-1}$ for September-October $\left(R^{2}=0.69\right)$ and almost $4 \mathrm{gC} \mathrm{m}^{-2}{ }^{\circ} \mathrm{C}^{-1}$ for November-December $\left(R^{2}=0.65\right)($ Fig. $4 \mathrm{c})$. 

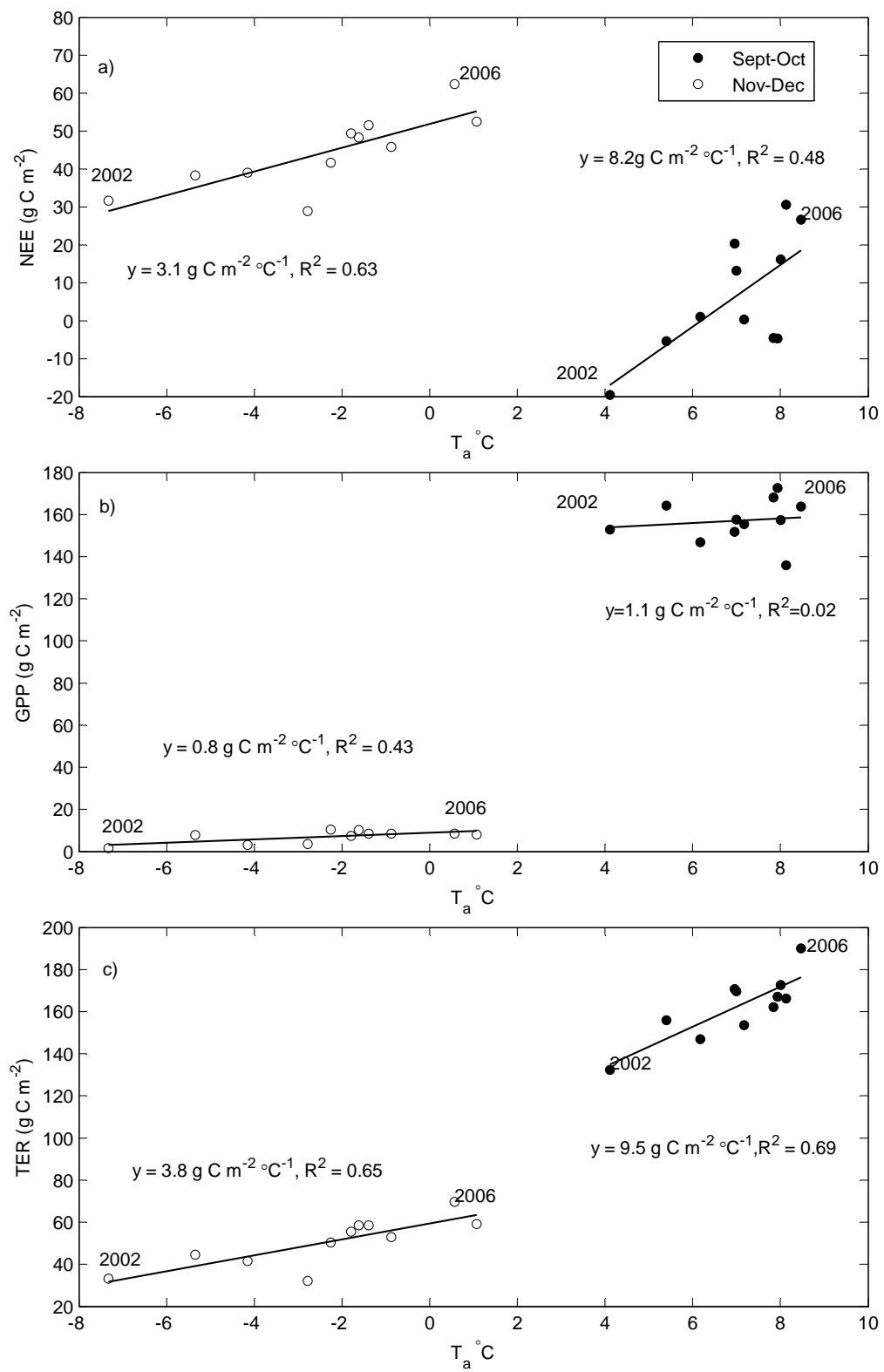

Fig. 4. Cumulative NEE (a), GPP (b) and TER (c) over the early (September-October) and late autumn (November-December) as a function of the average air temperature $\left(T_{a}\right)$ for the corresponding bimonthly periods. The linear least-squares regressions give the temperature sensitivities.

\subsection{Modelled temperature dependence of GPP in future scenarios}

The results above show that both the GPP and its temperature sensitivity were very small in the late autumn during the past eleven years. The small apparent temperature sensitivity can be largely attributed to the negative correlation of radiation and temperature in autumn (see Fig. 1 and Table 1 and 2). It is plausible that during colder periods, there are more night frosts that drop the day-time light use efficiency.
We consider next the GPP-temperature relationships in the present (that is past 11 years) climate and then under the elevated temperatures using the stand photosynthesis model COCA. The purpose here is to obtain the order of magnitude estimates for temperature sensitivity and thus the scenarios are simplified and include only the constant increase of the temperature by 3 or 6 degrees from the present $1 / 2$ hourly temperature records. Nevertheless, the used procedure is realistic enough to reveal interplay of GPP and temperature if the radiation and relative humidity would not 

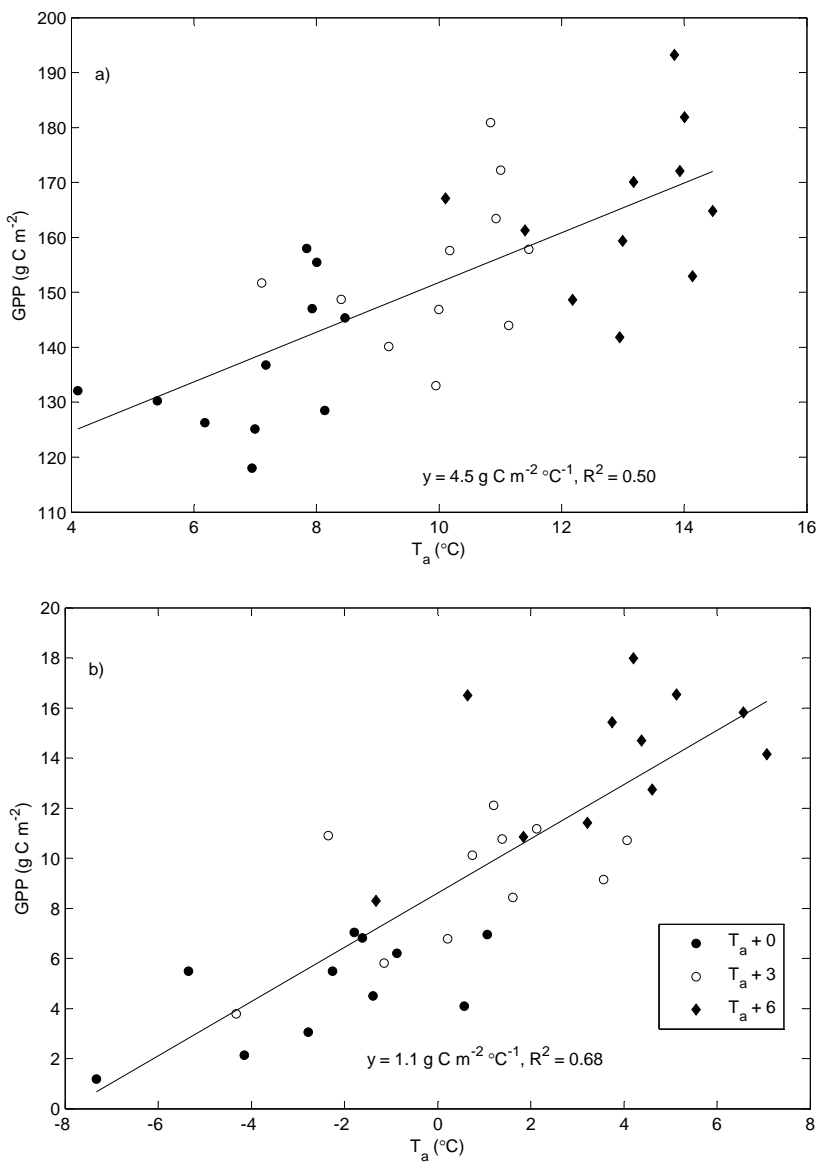

Fig. 5. Modeled cumulative GPP as a function of mean air temperature $\left(T_{a}\right)$ in early (September-October) (a) and late autumn (November-December) (b) periods. The different symbols show the three temperature scenarios (present, $+3{ }^{\circ} \mathrm{C}$ and $+6{ }^{\circ} \mathrm{C}$ ). The linear least-squares fit show the average temperature sensitivity over all data points in each panel.

change. The modeling results for the past 11 years were consistent with the measured fluxes (see Figs. 4 and 5). Daily GPP diminished steeply in autumn with lower PAR and shorter daylight hours. Even on clear days with temperature above zero, GPP in November and December was very low. The temperature sensitivity of the modeled GPP was of the same order of magnitude as the measured in present climate. There was no clear correlation between the mean temperature and GPP in early autumn (September-October, $R^{2}=$ $0.23)$ although the slope $\left(+4.7 \mathrm{gC} \mathrm{m}^{-2}{ }^{\circ} \mathrm{C}^{-1}\right)$ is steeper than measured $+1.1 \mathrm{gC} \mathrm{m}^{-2}{ }^{\circ} \mathrm{C}^{-1}$ (Fig. 4b). In the late autumn (November-December) the GPP-T relationship was more distinct but the absolute GPP so small that the increase in GPP per unit temperature was less than $0.6 \mathrm{gC} \mathrm{m}^{-2}{ }^{\circ} \mathrm{C}^{-1}$. In the model, the cold autumn of 2002 had not the lowest GPP because the early autumn was sunny. When all half-hourly temperatures were increased by $3{ }^{\circ} \mathrm{C}$ and $6^{\circ} \mathrm{C}$, the modeled GPP increased by about $4.5 \mathrm{gC} \mathrm{m}^{-2}{ }^{\circ} \mathrm{C}^{-1}\left(R^{2}=0.23\right)$ in September-October and $1.1 \mathrm{gC} \mathrm{m}^{-2}{ }^{\circ} \mathrm{C}^{-1}$ in NovemberDecember $\left(R^{2}=0.68\right)$. We assumed that the diurnal and the seasonal patterns of radiation remain the same in the warming climate. It is possible however, that with increasing temperature the cloudiness also increases which will reduce the predicted increase in GPP.

\subsection{Dynamic global vegetation model sensitivity tests}

The model runs by the dynamic global vegetation model (ORCHIDEE) were carried out using both daily and 1/2hourly meteorological forcing. The modeled response of NEE to temperature varied with the simulation time step (Fig. 6). For example, early autumn NEE derived from the simulation using 1/2-hourly forcing was increased by $+4.9 \mathrm{gC} \mathrm{m}^{-2}{ }^{\circ} \mathrm{C}^{-1}\left(R^{2}=0.10\right)$ in response to rising temperature, while simulation using daily forcing gave early autumn NEE to be negatively related to temperature $\left(-2 \mathrm{gC} \mathrm{m}^{-2}{ }^{\circ} \mathrm{C}^{-1}, R^{2}=0.13\right)$. Such a different response of NEE to early autumn temperature change was stemming from the sensitivity of GPP to the chosen forcing time step. In response to rising temperature, daily time step showed higher sensitivity of GPP $\left(12.2 \mathrm{gC} \mathrm{m}^{-2}{ }^{\circ} \mathrm{C}^{-1}, R^{2}=0.92\right)$ than half-hourly simulation $\left(4.1 \mathrm{gC} \mathrm{m}^{-2}{ }^{\circ} \mathrm{C}^{-1}, R^{2}=0.13\right)$. For TER the modeled sensitivity was more similar between half-hourly time step simulation $\left(8.9 \mathrm{gC} \mathrm{m}^{-2}{ }^{\circ} \mathrm{C}^{-1}\right)$ and daily time step simulation $\left(10.2 \mathrm{gC} \mathrm{m}^{-2}{ }^{\circ} \mathrm{C}^{-1}\right)$. The $1 / 2$ hourly forcing produced results which were closer to the observed relationships (see Fig. 4).

\section{Discussion}

The results revealed that the correlation between GPP and TER with the driving environmental factors changes intraannually, also during the autumn (September-December) when the air temperature and insolation drastically decrease. The outcome of the complicated non-linear dynamics is that the autumnal cumulative NEE and TER are significantly larger if the average air temperature is higher, while the effect of the temperature to the cumulative GPP is much weaker. This leads to the larger carbon release, observed during warmer autumns, from the studied pine forest (soil) to the atmosphere.

In early autumn the correlation between GPP and the air temperature was generally smaller than 0.2 while the correlation with radiation was around +0.8 . In October the correlation with the radiation decreased rapidly below the 0.5 level and gradually to zero during the late autumn. At the same time when the correlation with radiation dropped, the correlation of GPP with temperature increased rapidly and peaked to 0.5 in the middle of November. Also, the relationship between daily mean temperature and radiation changed during the autumn. In early September, high air temperature was associated with clear skies and the correlation between GPP 

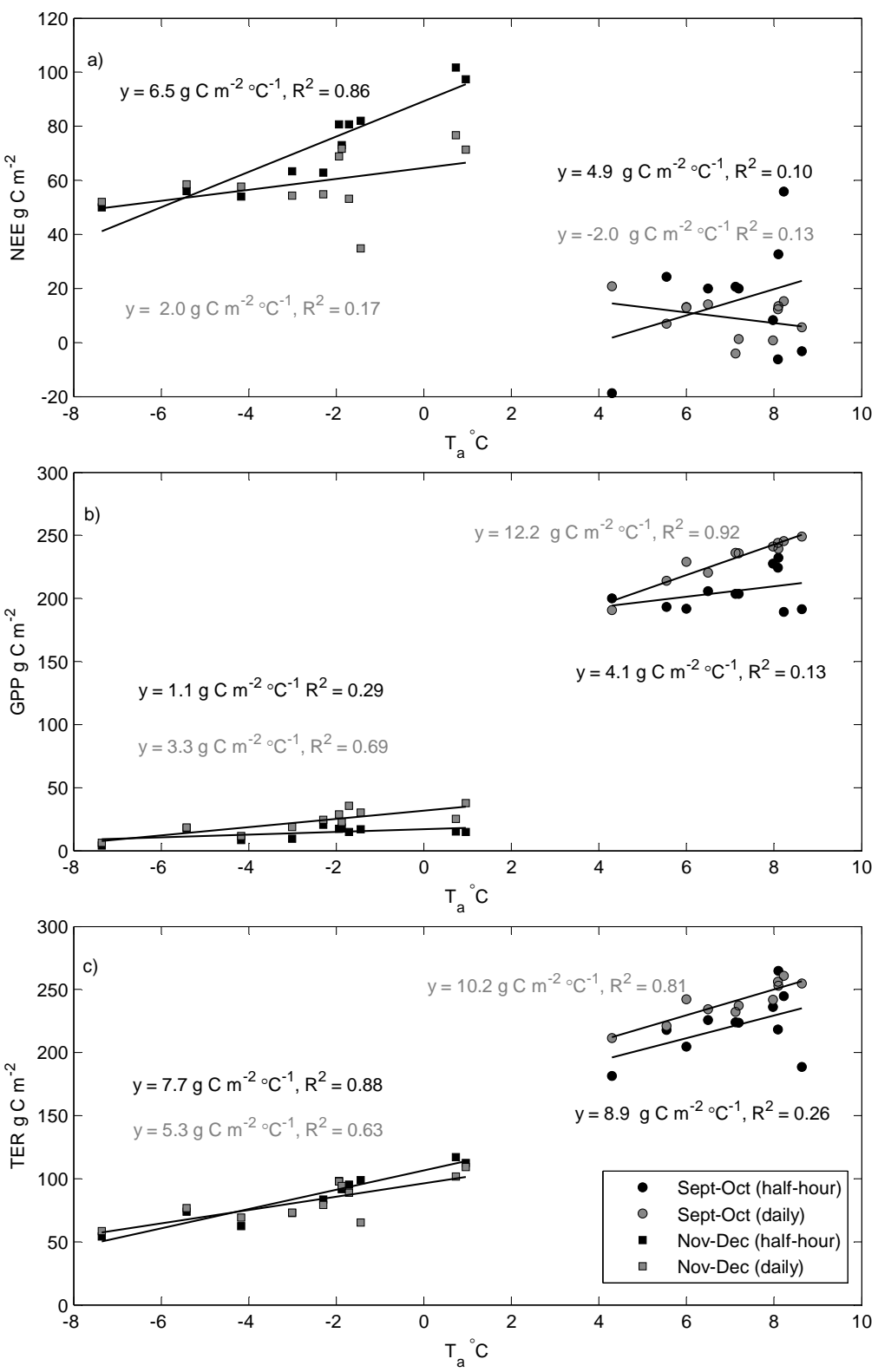

Fig. 6. Relationship of ORCHIDEE modeled NEE, GPP, and TER with temperature in early (September-October) and late autumn (November-December) periods. Two simulations at different time steps with half-hourly (circle) and daily (rectangle) time step are performed.

and air temperature was slightly positive $(r \sim+0.3)$ whereas in late autumn the correlation was negative $(-0.6$ in December). This behavior was caused by the appearance of the synoptic scale lows associated with warm westerlies coming from the North Atlantic that bring moist and warm air and produce cloudy skies over the Scandinavia. Thus, the warmest periods in late autumn and wintertime were typically associated with high cloudiness and large precipitation, conditions favorable for relatively high decomposition rates, of which contribution to TER is large in the autumn.
The highest temperature sensitivity for TER, almost $10 \mathrm{gC} \mathrm{m}^{-2}{ }^{\circ} \mathrm{C}^{-1}$, was found for September-October period. In late autumn the temperature sensitivity about $4 \mathrm{gC} \mathrm{m}^{-2}{ }^{\circ} \mathrm{C}^{-1}$ was close to the regional sensitivity found in Piao et al. (2008). The measured sensitivity of GPP at the same periods was only the order of $1 \mathrm{gC} \mathrm{m}^{-2}{ }^{\circ} \mathrm{C}^{-1}$. From the apparent temperature responses one could conclude that TER will increase more than GPP, implying that net ecosystem productivity will be reduced if autumn temperatures rise. However, plant respiration can also acclimate to 
changing temperature regimes (Atkin and Tjoelker, 2003). Furthermore, respiration and NEE are determined not only by environmental driving factors but also by the availability of photosynthates and demand for energy in the plant tissues (Gifford, 2003). The proportion of autotrophic respiration to GPP should be fairly stable when integrated over long periods of time, respiration being constrained by GPP (e.g. Dewar et al., 1998). Waring et al. (1998) suggested that net primary productivity, and correspondingly respiration, would be a constant ratio of GPP. Recently, a synthesis study over wide range of vegetation types showed a tight (positive) correlation between annual GPP and TER; a yearto-year differences in assimilation explained $\sim 60 \%$ of the inter-annual variability of respiration (Baldocchi, 2008). As a large part of $\mathrm{CO}_{2}$ efflux from heterotrophic respiration originates in prompt utilization of recently produced photosynthates (root exudates) (Pumpanen et al., 2008; Pumpanen et al., 2009) also long term TER would be roughly proportional to GPP. This means that in a warming climate the temporal distribution of the decomposition may change within a year although not necessarily the total cumulative decomposition. The stock of easily decomposable carbon would be exhausted already in the autumn and the soil $\mathrm{CO}_{2}$ efflux in spring would be correspondingly lower. In dark but warm winters the proportionality of annual respiration and GPP might break, however. Another issue is the delayed effects. Autumn 2002 was the coldest year during the whole September-December period and 2006 the warmest one for September-October and the second warmest for NovemberDecember, only 2000 was a bit warmer for the later period. Despite same temperature and moisture conditions, TER in December 2006 was much larger than in 2000. This may be because there could have been excess of rapidly decomposing litter left in the ground in autumn 2006 in the wake of the intensive August drought that strongly decreased both respiration and assimilation. Thus, the history of the ecosystem cannot be ignored.

The measured autumnal GPP was rather insensitive to the temperature under the present temperature regime. However, the photosynthesis model COCA, combined with the simple climate scenarios of 3 and 6 degrees temperature increases, predicted that GPP seems to have the temperature dependence even for November-December period when larger temperature range is considered. Note that the effects of atmospheric $\mathrm{CO}_{2}$ fertilization on photosynthesis and respiration are not considered here, neither the any carbonnitrogen coupling (see e.g. Hari et al., 2008b). The temperature sensitivities of the cumulative GPP and TER calculated by the dynamic global vegetation model were similar to the observation, when the 1/2-hourly time-step was used, which corroborates the finding by Piao et al. (2009) for the significance of TER for boreal region under the climate warming. However, the results using daily forcing data were biased towards too high temperature dependence of GPP leading to too low temperature dependence of NEE. This result not only implies that current biogeochemical models working on daily time steps (e.g., LPJ by Sitch et al., 2003; CASA by Potter et al., 1993; TEM by Mellilo et al., 1993) may be not able to correctly capture the response of carbon cycle to climate change, but also highlights the importance of high-resolution forcing data in current model application for projection of future carbon cycle. However, monthly time step of climate data is generally used in IPCC future scenarios of carbon cycle.

\section{Conclusions}

The long-term eddy-covariance measurements show that increasing autumn temperature enhances carbon efflux from the studied ecosystem, because respiration (TER) is strongly temperature dependent and it dominates over photosynthesis (GPP) especially during late autumn when radiation levels are low. However, it is not clear whether warm autumns increase overall carbon losses from the forest, or whether autumnal losses are counterbalanced by lowered respiration levels in the following spring. According to the stand photosynthesis model, a predescribed increase of $3-6^{\circ} \mathrm{C}$ in the air temperature would lead to more pronounced temperature sensitivity GPP, although still weaker than that of TER, in early autumn. This is partly due to diminishing of the freezing temperatures suppressing GPP. The generic dynamic vegetation model ORCHIDEE produced similar TER and GPP temperature sensitivities, to observations, when the 1/2hourly time-step was applied, but the daily time step strongly overestimated the GPP temperature dependence.

Acknowledgements. This research was supported by the Academy of Finland Center of Excellence program (project numbers 1118615 and 7523004), by the Academy of Finland project 213093 and by the Nessling Foundation. EU projects IMECC and ICOS are also acknowledged.

Edited by: A. Lindroth

\section{References}

Atkin, O. K. and Tjoelker, M. G.: Thermal acclimation and the dynamic response of plant respiration to temperature, Trends Plant Sci., 8, 343-351, 2003.

Aubinet, M., Grelle, A., Ibrom, A., Rannik, Ü., Monchrieff, J., Foken, T., Kowalski, A. S., Martin, P. H., Bergibier, P., Bernhofer, C., Clement, R., Elbers, J., Granier, A., Grünwald, T., Morgenstern, K., Pilegaard, K., Rebmann, C., Snicders, W., Valentini, R. and Vesala, T.: Estimates of the Annual Net Carbon and Water Exchange of Forests: The EUROFLUX Methodology, Adv. Ecol. Res., 30, 113-178, 2000.

Baldocchi, D. D.: Turner review no. 15: "Breathing" the terrestrial biosphere: lessons learned form a global network of carbon dioxide flux measurement systems, Australian J. Bot., 56, 1-26, 2008. 
Bergeron, O., Margolis, H. A., Black, T. A., Coursolle, C., Dunn, A. L., Barr, A. G., and Wofsy, S. C.: Comparison of carbon dioxide fluxes of three boreal black spruce forests in Canada, Glob. Change Biol., 13, 89-107, 2007.

Cajander, A. K.: Ueber Waldtypen, Acata For. Fenn., 1, 1-176, 1909.

Christensen, J. H., Hewitson, B., Busuioc, A., Chen, A., Gao, X., Held, I., Jones, R., Kolli, R. K., Kwon, W.-T., Laprise, R., Magaña Rueda, V., Mearns, L., Menéndez, C. G., Räisänen, J., Rinke, A., Sarr, A., and Whetton, P.: Regional Climate Projections, in: Climate Change 2007: The Physical Science Basis. Contribution of Working Group I to the Fourth Assessment Report of the Intergovernmental Panel on Climate Change. edited by: Solomon, S., Qin, D., Manning, M., Chen, Z., Marquis, M., Averyt, K. B., Tignor, M., and Miller, H. L., Cambridge University Press, Cambridge, United Kingdom and New York, NY, US, 2007.

Collatz, G. J., Ribas-Carbo, M., and Berry, J. A.: Coupled Photosynthesis-Stomatal Conductance Model for Leaves of C4 Plants, Aust. J. Plant Physiol., 19, 519-538, 1992.

Dewar, R. C., Medlyn, B. E., and McMurtrie, R. E.: A mechanistic analysis of light and carbon use efficiencies, Plant, Cell Environ., 21, 573-588, 1998.

Duursma, R, Kolari, P., Perämäki, M., Nikinmaa, E., Hari, P., Delzon, S., Loustau, D., Ilvesniemi, H., Pumpanen, J., and Mäkelä A.: Predicting the decline in daily maximum transpiration rate of two pine stands during drought based on constant minimum leaf water potential and plant hydraulic conductance, Tree Physiol., 28, 265-276, 2007.

FAO, Global Forest Resources Assessment 2000, FAO Forestry Papers, 140, 2000.

Farquhar, G. D., Caemmerer, S. V., and Berry, J. A: A BiochemicalModel of Photosynthetic $\mathrm{CO}_{2}$ Assimilation in Leaves of C-3 Species, Planta, 149, 78-90, 1980.

Gifford, R. M.: Plant respiration in productivity models: conceptualisation, representation and issues for global terrestrial carboncycle research, Funct. Plant Biol., 30, 171-186, 2003.

Hari, P., Mäkelä, A., Korpilahti, E., and Holmberg, M.: Optimal control of gas exchange, Tree Physiol., 2, 169-175, 1986.

Hari, P., Nikinmaa, E., Vesala, T., Pohja, T., Siivola, E., Lahti, T., Aalto, P., Hiltunen, V., Ilvesniemi, H., Keronen, P., Kolari, P., Grönholm, T., Palva, L., Pumpanen, J., Petäjä, T., Rannik, Ü., and Kulmala, M.: SMEAR network. in: Boreal Forest and Climate Change. Advances in Global Change Research 34, edited by: Hari, P. and Kulmala, L., Springer, 2008a.

Hari, P., Salkinoja-Salonen, M., Liski, J., Simojoki, A., Kolari, P., Pumpanen, J., Kähkönen, M., Aakala, T., Havimo, M., Kivekäs, R., and Nikinmaa, E.: Growth and development of forest ecosystems: the MicroForest Model. in: Boreal Forest and Climate Change. Advances in Global Change Research 34, edited by: Hari, P. and Kulmala, L., Springer, 2008b.

Högberg, P., Nordgren, A., Buchmann, N., Taylor, A. F. S., Ekblad, A., Högberg, M. N., Nyberg, G., Ottoson-Löfvenius, M., and Read, D. J.: Large-scale forest girdling shows that current photosynthesis drives soil respiration, Nature, 411, 789-792, 2001.

IPCC, Climate Change, The Physical Sciences Basis: Contribution of Working Group I to the Fourth Assessment Report of the Intergovernmental Panel on Climate Change, Cambridge Univ. Press, Cambridge, 2007.
Ilvesniemi, H., Levula, J., Ojansuu, R., Kolari, P., Kulmala, L., Pumpanen, J., Launiainen, S., Vesala, T. and Nikinmaa, E.: Long-term measurements of the carbon balance of a boreal Scots pine dominated forest ecosystem. Boreal Env. Res., 14, 731-753, 2009.

Kolari, P., Pumpanen, J., Kulmala, L., Ilvesniemi, H., Nikinmaa, E., Grönholm, T., and Hari P.: Forest floor vegetation plays an important role in photosynthetic production of boreal forests, Forest Ecol. Manag., 221, 241-248, 2006.

Kolari, P., Lappalainen, H. K., Hänninen, H., and Hari, P.: Relationship between temperature and the seasonal course of photosynthesis in Scots pine at northern timberline and in southern boreal zone, Tellus 59B, 542-552, 2007.

Kolari, P., Kulmala, L., Pumpanen, J., Launiainen, S., Ilvesniemi, H., Hari, P., and Nikinmaa, E.: $\mathrm{CO}_{2}$ exchange and component $\mathrm{CO}_{2}$ fluxes of a boreal Scots pine forest, Boreal Environ. Res., 14, 761-783, 2009.

Krinner, G., Viovy, N., de Noblet-Ducoudre, N., et al.: A dynamic global vegetation model for studies of the coupled atmosphere-biosphere system, Global Biogeochem. Cy., 19, GB1015, doi:10.1029/2003GB002199, 2005.

Kulmala, L., Launiainen, S., Pumpanen, J., Lankreijer, H., Lindroth, A., Hari, P., and Vesala, T.: $\mathrm{H}_{2} \mathrm{O}$ and $\mathrm{CO}_{2}$ fluxes at the floor of a boreal pine forest, Tellus 60B, 167-178, 2008.

Lagergren, F., Lindroth, A., Dellwik, E., Ibrom, A., Lankreijer, H., Launiainen, S., Mölder, M., Kolari, P., Pilegaard, K., and Vesala, T.: Biophysical controls on $\mathrm{CO}_{2}$ fluxes of three Northern forests based on long-term eddy covariance data, Tellus 60B, 143-152, 2008.

Larcher, W.: Physiological plant ecology, Springer-Verlag, 1975.

Lloyd J. and Taylor J. A.: On temperature dependence of soil respiration, Funct. Ecol., 8, 315-323, 1994.

Mäkelä, A., Hari, P., Berninger, F., Hänninen, H., and Nikinmaa, E.: Acclimation of photosynthetic capacity in Scots pine to the annual cycle of temperature, Tree Physiol., 24, 369-376, 2004.

Mäkelä, A., Kolari,P., Karimäki, J., Nikinmaa, E., Perämäki, M., and Hari, P.: Modelling five years of weather driven variation of GPP in a boreal forest, Agric. Forest Meteorol., 139, 382-398, 2006.

Markkanen, T., Rannik, Ü., Keronen, P., Suni, T., and Vesala, T.: Eddy covariance fluxes over a boreal Scots pine forest, Boreal Environ. Res., 6, 65-78, 2001.

Melillo, J. M., McGuire, A. D., Kicklighter, D. W., Moore, B., Vorosmarty, C. J., and Schloss, A. L.: Global Climate-Change and Terrestrial Net Primary Production, Nature, 363, 234-240, 1993.

Parton, W. J., Stewart, J. W. B., and Cole, C. V., Dynamics of C, N, P and S in Grassland Soils - a Model, Biogeochemistry, 5, 109-131, 1988.

Pelkonen, P. and Hari, P.: The dependence of the springtime recovery of $\mathrm{CO}_{2}$ uptake in Scots pine on temperature and internal factors, Flora, 169, 398-404, 1980.

Peltola, H.: Yearbook of Forest Statistics (in Finnish), Finn. For. Res. Inst., Vammala, Finland, 2001.

Piao, S. L., Ciais, P., Friedlingstein, P., Peylin, P., Reichstein, M., Luyssaert, S., Margolis, H., Fang, J. Y., Barr, L., Chen, A. P., Grelle, A., Hollinger, D., Laurila, T., Lindroth, A., Richardson, A. D., and Vesala, T.: Net carbon dioxide losses of northern ecosystems in response to autumn warming, Nature, 451, 49-52, 
2008.

Post, W. M., Emanuel, W. R., Zinke, P. J., and Stangenbauer, A. G.: Soil carbon pools and world life zones, Nature, 298, 156-159, 1982.

Potter, C. S., Randerson, J. T., Field, C. B., Matson, P. A., Vitousek, P. M.: Mooney, H. A., and Klooster, S. A.: Terrestrial ecosystem production: a process model based on global satellite and surface data, Global Biogeochem. Cy., 7, 811-841, 1993.

Pumpanen, J., Heinonsalo, J., Rasilo, T., Hurme, K.-R., and Ilvesniemi, H.: Carbon balance and allocation of assimilated $\mathrm{CO}_{2}$ in Scots pine, Norway spruce and Silver birch seedlings determined with gas exchange measurements and ${ }^{14} \mathrm{C}$ pulse labeling, Trees -Structure Function, 611-621, doi:10.1007/s00468-008-0306-8, 2009.

Pumpanen, J., Ilvesniemi, H., Kulmala, L., Siivola, E., Laakso, H., Helenelund, C., Laakso, M., Uusimaa, M., Iisakkala, P., Räisänen, J., and Hari, P.: Respiration in boreal forest soil as determined from carbon dioxide concentration profile, Soil Sci. Soc. America J., 72, 1187-1196, 2008.

Reichstein, M., Falge, E., Baldocchi, D., Papale, D., Aubinet, M., Berbigier, P., Bernhofer, C., Buchmann, N., Gilmanov, T., Granier, A., Grünwald, T., Havránková, K., Ilvesniemi, H., Janous, D., Knohl, A., Laurila, T., Lohila, A., Loustau, D., Matteucci, G., Meyers, T., Miglietta, F., Ourcival, J.-M., Pumpanen, J., Rambal, S., Rotenberg, E., Sanz, M., Tenhunen, J., Seufert, G., Vaccari, F., Vesala, T., Yakir, D., and Valentini, R.: On the separation of net ecosystem exchange into assimilation and ecosystem respiration: review and improved algorithm, Glob. Change Biol., 11, 1-16, doi:10.1111/j.13652486.2005.001002.x., 2005.
Running, S. W. and Gower, S.T.: FOREST-BGC, A general model of forest ecosystem processes for regional applications II, Dynamic carbon allocation and nitrogen budgets, Tree Physiol., 9, 147-160, 1991.

Schlesinger, W. H.: Carbon balance in terrestrial detritus, Annual Rev. Ecol. Systematics, 51-81, 1977.

Sevanto, S., Suni, T., Pumpanen, J., Grönholm, T., Kolari, P., Nikinmaa, E., Hari, P., and Vesala, T.: Wintertime photosynthesis and water uptake in a boreal forest, Tree Physiol., 26, 749-757, 2006.

Sitch, S., Smith, B., Prentice, I. C., Arneth, A., Bondeau, A., Cramer, W., Kaplan, J. O., Levis, S., Lucht, W., Sykes, M. T., Thonicke, K., and Venevsky, S.: Evaluation of ecosystem dynamics, plant geography and terrestrial carbon cycling in the LPJ dynamic global vegetation model, Glob. Change Biol., 9, 161$185,2003$.

Suni, T., Berninger, F., Markkanen, T., Keronen, P., Rannik, Ü., and Vesala, T.: Interannual variability and timing of growing-season $\mathrm{CO}_{2}$ exchange in a boreal forest, J. Geophys. Res., 108, 4265, doi:10.1029/2002JD002381, 2003.

Vesala, T., Markkanen, T., Palva, L., Siivola, E., Palmroth, S., and Hari, P.: Effect of variations of PAR on $\mathrm{CO}_{2}$ exchange estimation for Scots pine, Agric. Forest Meteorol., 100, 337-347, 2000.

Vesala, T., Suni, T., Rannik, Ü., Keronen, P., Markkanen, T., Sevanto, S., Grönholm, T., Smolander, S., Kulmala, M., Ilvesniemi, H., Ojansuu, R., Uotila, A., Levula, J., Mäkelä, A., Pumpanen, J., Kolari, P., Kulmala, L., Altimir, N., Berninger, F., Nikinmaa, E., and Hari, P.: The effect of thinning on surface fluxes in a boreal forest, Global Biogeochem. Cy., 19, GB2001, doi:10.1029/2004GB002316, 2005.

Waring, R. H., Landsberg, J. J., and Williams, M.: Net primary production of forests: a constant fraction of gross primary production?, Tree Physiol., 18, 129-134, 1998. 